\title{
DNA hybridisation of cervical scrapes: comparison with cytological findings in Papanicolaou smears
}

\author{
ANNE R MORSE, ${ }^{*}$ C WICKENDEN, ${ }^{*} \dagger$ MICHELINE BYRNE, $\ddagger$ \\ D TAYLOR-ROBINSON, $\ddagger$ JENNIFER SMITH, * M C ANDERSON,* \\ CONAMORE SMITH, $\uparrow$ A D B MALCOLM, $\dagger$ DULCIE V COLEMAN*
}

From the *Department of Pathology, St Mary's Hospital Medical School, the †Department of Biochemistry, Charing Cross Hospital Medical School, the $\ddagger$ Praed Street Clinic, St Mary’s Hospital, London and the \Raymede Family Clinic, London

SUMMARY One hundred and sixty four cervical scrapes were taken over 26 months from 143 women aged 17 to 53 years, using an Ayre spatula. A smear was prepared from each sample for Papanicolaou staining and for cytological examination for evidence of human papillomavirus (HPV) infection. The cells remaining on the spatula were harvested for DNA analysis. These samples were probed for HPV 6,16 , and 18 and the results of DNA hybridisation and cytology were compared. Cytological changes of HPV (anucleate keratinised and keratinised squamous cells, koilocytic change and dyskeratosis, or multinucleation, or both) were detected in $103(72 \%)$ of the samples where HPV DNA was detected; koilocytic changes were present in only $67(48 \%)$.

It is concluded that screening for a range of viral changes is a more sensitive method of detecting HPV infection than screening for koilocytic change alone.

Cytological, histological, and colposcopic features associated with human papillomavirus (HPV) infection of the cervix uteri are well known..$^{1-3}$ Cells showing koilocytic change, multinucleation, and dyskeratosis, with the addition of anucleate keratinised squamous cells and keratinised squamous cells have been described as features indicative of infection with HPV. It is accepted, however, that koilocytic change is the most important of these features, and it is often this feature alone which is regarded as pathognomonic of the infection. These variables are, however, subjective and more objective laboratory confirmation of the association is desirable. Immunocytochemistry, electron microscopy, and more recently, DNA hybridisation have been used.

As a result of comparative studies, ${ }^{45}$ it has been suggested that DNA hybridisation is the most sensitive method of detecting HPV infection and that alternative indicators including cytological analysis are unreliable. DNA hybridisation is expensive and time consuming; cervical cytology, on the other hand, is an established screening method for cervical

Accepted for publication 25 September 1987 intraepithelial neoplasia (CIN) so that screening for HPV infection by this method could be included easily in a routine programme. We considered it important, therefore, to evaluate fully the extent to which cytological changes seen in routine cervical smears correlated with the presence of HPV DNA in cervical scrape specimens taken at the same time.

\section{Material and methods}

One hundred and sixty four cervical scrapes were taken over 26 months from 143 women aged 17 to 53 years attending the sexually transmitted disease (STD) clinic or family planning services at St Mary's Hospital, or the colposcopy clinic at the Samaritan Hospital. A smear was prepared and fixed in $95 \%$ alcohol for Papanicolaou staining and examined by light microscopy for malignant or dyskaryotic cells. In addition, the presence of anucleate keratinised squamous cells, keratinised squamous cells, koilocytes, dyskeratotic cells and multinucleate cells was noted. Keratinised and anucleate keratinised cells were characterised by the presence of orangeophilic and yellow staining cytoplasm, rarely of a refractile quality, but always occurring in sheets or plaques 
where cell borders were poorly defined. Individual cells with intensely orangeophilic and often birefringent cytoplasm and densely stained, often fragmented nuclei were classified as dyskeratotic. Koilocytes were defined as squamous cells displaying an enlarged nucleus with nuclear changes not sufficiently exaggerated to be regarded as fulfilling the criteria of dyskaryosis, but showing a large, well defined irregularly shaped perinuclear halo and a more densely stained ring of cytoplasm at the rim of the halo. Multinucleate in this context was interpreted as a squamous cell with or without koilocytic change and containing two or more nuclei. Multinucleation rarely exceeded four nuclei.

The end of the cervical spatula was broken off and immersed in phosphate buffered saline $(20 \mathrm{ml})$ and stored at $-20^{\circ} \mathrm{C}$. The specimens were examined subsequently for DNA hybridisation by the dot blot method at high stringency. ${ }^{6}$ The purified DNA was spotted on to zetaprobe nylon membrane filters using a Biodot 96 well suction manifold and hybridised to a probe to one of three viral types 6,16 , and 18 under the following conditions. Prehybridisation was carried out overnight at $42{ }^{\circ} \mathrm{C}$ in a solution of $0.05 \%$ sodium dodecyl sulphate, $0.08 \mathrm{M}$ Tris-hydrochloric acid $(\mathrm{pH}$ 7.8), $0.004 \mathrm{M}$ edetic acid; $0.75 \mathrm{M}$ sodium chloride; 0.1 $\mathrm{mg} / \mathrm{ml}$ sonicated denatured salmon sperm DNA, deionised formamide $50 \%$. The filters were then sequentially hybridised to DNA probes of the three different viral types labelled to a high specific activity with ${ }^{32} \mathrm{P}$ by random oligomeric primer extension. High stringency was achieved by washing in $0 \cdot 1 \times$ SCC, $0 \cdot 1 \%$ sodium dodecyl sulphate for three one hourly washes at $65^{\circ} \mathrm{C}$. (This minimises cross hybridisation, reducing it to an amount that is not detectable by any current method.) After washing, the filters were exposed to preflashed Fuji RX-100 film for 14 days at $-70^{\circ} \mathrm{C}$ and autoradiography was carried out using a Joyce Loebl integrating densitometric scanner. Between hybridisation with the different probes, the bound probe was washed off using a solution of $0.5 \times$ SSC, $0 \cdot 1 \%$ sodium dodecyl sulphate at $95^{\circ} \mathrm{C}$ cooling to $65^{\circ} \mathrm{C}$ for three one hour washes.

\section{Results}

Of the 164 cervical smears, 124 were regarded as "normal" with no cytological features suggestive of
Table 1 Evidence of human papillomavirus (HPV) in 164 cervical scrape specimens (figures in parentheses are numbers \%)

Cytological features of HPV infection

Koilocytic change

$67(41)$

HPV DNA

Cytological features and HPV DNA

$40(24)$

$64(39)$

$48(29)$

CIN. There were, therefore, 40 smears from 19 women with cytologically, colposcopically, and histologically confirmed CIN that contained dyskaryotic cells. Of these abnormal smears, 39 were from 18 women attending the STD clinic.

Cytological changes suggestive of HPV infection were seen in $67(41 \%)$ of the 164 specimens, with koilocytic change in $40(24 \%)$ of the specimens. HPV DNA was detected in $64(39 \%)$ of the specimens, but not necessarily in the same ones. Indeed, in only 48 $(29 \%)$ of the specimens were HPV DNA and cytological changes found together (table 1). Thus 19 $(12 \%)$ of the specimens had cytological features suggestive of HPV infection but no HPV DNA was detected, and $16(10 \%)$ of the specimens contained HPV DNA without cytological changes.

The distribution of the individual cytological features in the group of specimens where HPV DNA was found and in the group where HPV DNA was not found is shown in table 2 . Of the 64 specimens in which HPV DNA was detected, keratinisation was seen in 44 $(69 \%)$. Koilocytes were seen in only $31(48 \%)$ and other changes in a smaller proportion. Of the 100 specimens in which HPV DNA was not detected, cytological changes suggestive of HPV infection were seen in only a small proportion. Of the 19 specimens in which changes were seen, 17 had those of keratinisation and only nine of those koilocytic change. Anucleate keratinised squamous cells were present in four, multinucleation in three, and dyskeratosis in five. Thus in both groups keratinisation was the most prominent cytological feature.

\section{ASSOCIATION BETWEEN CYTOLOGICAL AND VIROLOGICAL FINDINGS IN THE "NORMAL" GROUP}

The distribution of viral types and the cytological features of HPV infection associated with them in the 124 specimens without cytological changes of CIN are shown in table 3. HPV type 6 was found in 19 of the

Table 2 Correlation between HPV DNA and cytological features of HPV infection in 164 specimens

\begin{tabular}{|c|c|c|c|c|c|c|c|}
\hline \multirow{2}{*}{$\begin{array}{l}\text { Presence of } \\
H P V D N A\end{array}$} & \multirow{2}{*}{$\begin{array}{l}\text { No of } \\
\text { specimens }\end{array}$} & \multicolumn{6}{|c|}{ Cytological features } \\
\hline & & Anucleate & Keratinised squamous cells & Koilocytic & Multinucleation & Dyskeratosis & None \\
\hline $\begin{array}{l}\text { HPV DNA } \\
\text { No HPV DNA }\end{array}$ & $\begin{array}{r}64 \\
100\end{array}$ & $\begin{array}{r}15 \\
4\end{array}$ & $\begin{array}{l}44 \\
17\end{array}$ & $\begin{array}{r}31 \\
9\end{array}$ & $\begin{array}{r}13 \\
3\end{array}$ & $\begin{array}{r}12 \\
5\end{array}$ & $\begin{array}{l}16 \\
81\end{array}$ \\
\hline
\end{tabular}


Table 3 Correlation between HPV DNA and cytological features of HPV infection in 124 cytologically normal specimens

\begin{tabular}{|c|c|c|c|c|c|c|c|}
\hline \multirow{2}{*}{$\begin{array}{l}\text { Presence of* } \\
H P V D N A\end{array}$} & \multirow{2}{*}{$\begin{array}{l}\text { No of } \\
\text { specimens }\end{array}$} & \multicolumn{6}{|c|}{ Cytological features } \\
\hline & & Anucleate & Keratinised squamous cells & Koilocytic & Multinucleation & Dyskeratosis & None \\
\hline $\begin{array}{l}\text { HPV } 6 \text { alone } \\
\text { HPV } 16 \text { alone } \\
\text { More than one HPV } \\
\text { type }\end{array}$ & $\begin{array}{r}19 \\
6 \\
9\end{array}$ & $\begin{array}{l}0 \\
1 \\
4\end{array}$ & $\begin{array}{l}8 \\
3 \\
6\end{array}$ & $\begin{array}{l}8 \\
2 \\
6\end{array}$ & $\begin{array}{l}1 \\
0 \\
0\end{array}$ & $\begin{array}{l}2 \\
0 \\
1\end{array}$ & $\begin{array}{l}8 \\
2 \\
3\end{array}$ \\
\hline No viral DNA & 90 & 1 & 10 & 4 & 0 & 0 & 80 \\
\hline
\end{tabular}

*HPV type 18 alone not found in any specimens.

specimens, but type 16 was found in six. Nine specimens harboured more than one viral type.

Forty two per cent of specimens with type 6 virus were associated with one or more cytological features. Roughly the same proportion of specimens with type 16 viral DNA also showed cytological changes, although only a third showed koilocytic change. Keratinisation and koilocytic change were seen in six of the specimens where more than one viral type was found.

Eighty of the 90 specimens that did not contain viral DNA also did not exhibit cytological features of HPV infection. Of the 10 specimens that did show cytological changes, keratinisation was present in all of them, but koilocytic change in only four.

\section{ASSOCIATION BETWEEN CYTOLOGICAL AND VIROLOGICAL FINDINGS IN THE ABNORMAL GROUP}

The distribution of viral types and the cytological changes of HPV infection in the 40 specimens with CIN are shown in table 4 . Thirty of the 40 specimens contained HPV DNA, with HPV type 6 being found in five of the specimens, and type 16 in 21 of them. Cytological evidence of HPV infection was detected in 27 of the $30(90 \%)$ of the HPV DNA positive samples. Eighty per cent of specimens with type 6 virus were associated with keratinisation and $100 \%$ with koilocytic change. In the case of HPV type 16, keratinisation was noted in $95 \%$ of the specimens and koilocytic change in $38 \%$. Multinucleation was noted in $47 \%$ of this subgroup.

Three specimens with HPV type 16, detected by hybridisation, showed no cytological features of HPV infection, but there were 10 specimens with cytological features suggestive of HPV infection in which HPV DNA was not detected. Keratinisation was seen in seven of these specimens and koilocytic change in five.

\section{Discussion}

Overall, HPV infection on cervical scrape samples was identified more often by cytological examination than by DNA hybridisation. Cellular changes in cervical smears, however, were not seen in $16(10 \%)$ of cases in which DNA hybridisation detected HPV DNA. On the other hand, cytological features suggestive of HPV infection were seen in 19 cases in which DNA hybridisation was negative. This may reflect the lack of specificity of the cytological features, or a lack of sensitivity of the DNA probes. The DNA hybridisation technique, however, can detect small amounts of viral DNA, to less than 10 copy numbers per cell, although this is a mean calculation, and not, therefore, based on any individual cell. Thus a sampling error may account for some of the negative findings.

In an attempt to assess this aspect further, eight smears in which there were cells showing features of keratinisation and koilocytic change but where no viral DNA was detected, and one smear where both cytological examination and HPV DNA identified HPV infection, were reprocessed for electron microscopy. The method has been described previously. ${ }^{7}$ No viral particles were identified. Although this is disappointing and does not offer additional confirmation for the cytological diagnosis of HPV infection, it is accepted that electron microscopy is limited for this. ${ }^{8}$

Table 4 Correlation between HPV DNA and cytological features of HPV infection in 40 cytologically abnormal specimens

\begin{tabular}{|c|c|c|c|c|c|c|c|}
\hline \multirow{2}{*}{$\begin{array}{l}\text { Presence of } \\
H P V D N A\end{array}$} & \multirow{2}{*}{$\begin{array}{l}\text { No of } \\
\text { specimens }\end{array}$} & \multicolumn{6}{|c|}{ Cytological features } \\
\hline & & Anucleate & Keratinised squamous cells & Koilocytic & Multinucleation & Dyskeratosis & None \\
\hline $\begin{array}{l}\text { HPV } 6 \text { alone } \\
\text { HPV } 16 \text { alone } \\
\text { More than one HPV } \\
\text { type }\end{array}$ & $\begin{array}{r}5 \\
21 \\
4\end{array}$ & $\begin{array}{l}3 \\
5 \\
2\end{array}$ & $\begin{array}{r}4 \\
20 \\
3\end{array}$ & $\begin{array}{l}5 \\
8 \\
2\end{array}$ & $\begin{array}{r}1 \\
10 \\
1\end{array}$ & $\begin{array}{l}4 \\
3 \\
2\end{array}$ & $\begin{array}{l}0 \\
3 \\
0\end{array}$ \\
\hline No HPV DNA & 10 & 3 & 7 & 5 & 3 & 5 & 1 \\
\hline
\end{tabular}

${ }^{*} \mathrm{HPV}$ type 18 alone not found in any specimens. 
Apart from the association between the cytological and HPV DNA results, another interesting finding was the relatively high incidence of HPV infection. All three virus types were found in both the normal and abnormal groups of specimens. The findings of HPV is of clinical importance in view of the association of these particular virus types with intraepithelial neoplasia and invasive carcinoma of the cervix. ${ }^{9}$ Although HPV type 16 was found in $24(60 \%)$ of patients with CIN 3 and in only one of five specimens from those with CIN 1, the small number of patients and the sequential nature of the specimens from some of them preclude analysis of prevalence and incidence. Nor can conclusions be drawn regarding the reproducibility and consistency of individual cytological features, as it was not the aim of this study to collect these data.

There was a relatively high incidence of HPV infection in the women without cytological evidence of CIN ("normal" group). About $27 \%$ harboured HPV, $5 \%$ of which was type 16 - one of the so called "high risk" types. Several of these patients have had cervical smears examined 18 months after the initial smear and two have had colposcopy, but so far, none of them has developed cervical abnormalities. These patients, however, require careful follow up as they may have an increased risk of developing intraepithelial neoplasia. $^{10}$

By using the cytological features of anucleate keratinised squamous cells, keratinisation, koilocytic change, multinucleation and dyskeratoisis, alone or with two or more in combination, we were able to detect HPV infection in $72 \%$ of the specimens where HPV DNA was found; koilocytic change alone was seen in only $48 \%$. We conclude, therefore, that a more sensitive method of detecting HPV infection at no additional cost to the current screening programme would be to assess all the cytological features mentioned rather than koilocytic change alone.

We thank Miss T Burge for typing the manuscript.

\section{References}

1 Meisels A, Fortin R. Condylomatous lesions of the cervix and vagina I. Cytologic patterns. Acta Cytol 1976;20:505-9.

2 Meisels A, Fortin R, Roy M. Condylomatous lesions of the cervix, cytologic, colposcopic and histopathological study. Acta Cytol 1977;21:379-90.

3 Reid R, Laverty CR, Coppleson M, et al. Non condylomatous wart virus infection. Obstet Gynecol 1980;55:476-83.

4 Kurman RJ, Sanz LE, Jenson B, et al. Papillomavirus infection of the cervix I correlation of histology with viral structural antigens and DNA sequences. Int J Gynecol Pathol 1982;1:1728.

5 McCance DJ, Walker PG, Dyson JL, et al. Presence of human papillomavirus DNA in cervical intraepithelial neoplasia (CIN). Br Med J 1983;287:784-8.

6 Wickenden C, Steele A, Malcolm ADB, et al. Screening for wart virus infection in normal and abnormal cervices by DNA hybridisation of cervical scrapes. Lancet 1985;i:65-7.

7 Coleman DV, Russell WJI, Hodgson J, et al. Human papovavirus in Papanicolaou smear of urinary sediment detected by transmission electron microscopy. J Clin Pathol 1977;30:1015-20.

8 Ferenczy A, Braun L, Shah KV. Human papillomavirus (HPV) in condylomatous lesions of cervix. A comparative ultrastructure and immunohistochemical study. Am J Surg Pathol 1981;5:66170.

9 Durst M, Kleinheinz A, Hotz M, et al. The physical state of human papillomavirus type 16 DNA in benign and malignant genital tumours. J Gen Virol 1985;66:1515-22.

10 Zur Hausen $H$. Intracellular surveillance of persisting viral infections. Human genital cancer results from deficient cellular control of papillomavirus gene expression. Lancet 1986;ii:48991.

Requests for reprints to: Mrs Anne R Morse, Department of Pathology, St Mary's Hospital Medical School, London W12 1PG, England. 